\title{
Disputas e debates sobre a colonização do estado de Mato Grosso nas páginas da Revista Brasil-Oeste*
}

\section{Disputes and debates on the colonization of the State of Mato Grosso in the pages of the Brasil-Oeste Magazine}

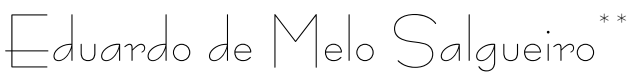

\section{Introdução}

A revista Brasil-Oeste foi criada pelo jornalista Fausto Vieira de Campos. Esse mensário foi produzido na cidade de São Paulo-SP, pela Brasil-Oeste Editôra Ltda. ${ }^{1}$ Seu período de circulação se estendeu entre janeiro de 1956 e agosto de 1967, totalizando a publicação de 123 edições. Campos dedicou boa parte de sua carreira jornalística a escrever sobre o estado de Mato Grosso, interesse despertado nos anos iniciais da década de 1950 em decorrência de sua passagem por Cáceres

\footnotetext{
* Este artigo é uma versão modificada do terceiro capítulo da dissertação apresentada ao Programa de Pós-Graduação em História da Universidade Federal da Grande Dourados (UFGD), sob orientação do Prof. Dr. Paulo Roberto Cimó Queiroz e financiada pela Capes (Conselho de Aperfeiçoamento de Pessoal de Nivel Superior) intitulada "O maior projeto em prol de Mato Grosso": uma análise da revista Brasil-Oeste (1956-1967). 183f. Dourados/MS, 2011.

** Mestre em História pela Universidade Federal da Grande Dourados (UFGD). E-mail: eduardomsalgueiro@gmail.com

${ }^{1}$ Essa editora contava com dois sócios, Fausto Vieira de Campos (sócio-majoritário) e seu filho, Fausto M. G. V. de Campos (sócio-minoritário). Informações retiradas da Certidão Simplificada. Contrato Social de Brasil-Oeste Editôra. Ano de 1957, Junta Comercial do Estado de São Paulo.
} 
e Cuiabá, ${ }^{2}$ sobretudo após ter assumido o cargo de assessor de imprensa (1954) do então governador do estado Fernando Corrêa da Costa (UDN). ${ }^{3}$ Adquiriu prestígio e destaque no Centro-Oeste do país, especialmente após a publicação de sua obra Retrato de Mato Grosso, no ano de 1955, na qual realizou uma abordagem geoeconômica da região. Seu livro, que mereceu duas outras publicações, nos anos de 1960 e 1969, foi o primeiro passo para a editoração da revista BrasilOeste. $^{4}$

Fausto Vieira de Campos reuniu em torno de si e de seu projeto uma gama de colaboradores e correspondentes. Mensalmente, a linha editorial da Brasil-Oeste se dava em duas frentes principais, sendo que a primeira procurava dar conta de tornar visiveis as potencialidades existentes no estado de Mato Grosso, com especial relevância para as oportunidades existentes na agropecuária. Para tal objetivo, seu segundo tópico principal consistia em reclamar frente ao poder público, sobretudo da esfera Federal, um plano concreto que acelerasse o desenvolvimento de Mato Grosso, encarado como "atrasado" tão somente por falta de vontade política e ausência de um órgão de imprensa que tornasse visivel os anseios mato-grossenses.

O momento era especial para tal tarefa, uma vez que a imprensa passava por modificações impressionantes, tanto no que diz respeito às novas possibilidades de produção e distribuição, aumento de publicidade, barateamento de custo, mas também o papel de reformulação da profissão jornalística. No Brasil, o jornalista tentava se desfazer um pouco da imagem de mero reprodutor da fala politica. Para tanto, buscava-se a "mítica da objetividade [...] fundamental para dar ao campo

\footnotetext{
${ }^{2}$ Fausto Vieira de Campos trabalhou para o jornal Folha da Manhã entre os anos de 1953-1955. Nesse periodo, o jornalista ficava encarregado de fazer reportagens exclusivamente sobre o estado de Mato Grosso.

${ }^{3}$ Fernando Corrêa da Costa governou o estado de Mato Grosso por duas vezes, entre os anos de 1951-1956 e 1961-1965. Em ambas as situações representando o partido da União Democrática Nacional (UDN).

${ }^{4}$ É válido dizer que a primeira edição foi feita sem vínculo com nenhuma editora e, aparentemente, com apoio do estado de Mato Grosso. A segunda e a terceira edições foram publicadas pela Brasil-Oeste Editôra Ltda.
} 
lugar autônomo e reconhecido, construindo o jornalismo como a única atividade capaz de decifrar o mundo para o leitor". ${ }^{5}$ Esse era um dos passos necessários para a profissão jornalistica ganhar mais respeito e representatividade junto à sociedade, sendo capaz de reproduzir os acontecimentos da melhor maneira para o seu leitor, de modo que esse compreendesse os fatos da realidade por meio da palaura do jornalista.

Por conta disso, o "discurso jornalístico passou a se revestir de uma 'aura de fidelidade aos fatos', que lhe conferiu um considerável poder social". ${ }^{6}$ Assim, não será apenas no campo político que exercerá sua força, "mas, sobretudo, conseguir mobilização maior do público. Quanto maior a sua audiência, maior sua divulgação e a lógica da conquista do próprio poder", assim, o "momento social da década de 1950", se faz crucial para uma imprensa que quer se transformar em porta-voz "da modernização". ${ }^{7}$ Assim, Fausto Vieira de Campos sentia-se como aquele cuja missão era fazer "ecoar" as vozes do "esquecido" estado de Mato Grosso, ele queria fazer valer o poder e a credibilidade de sua profissão, para tornar mais "respeitada" e "reconhecida" aquela região.

Nesse sentido, a revista Brasil-Oeste, tal como qualquer veículo de informação, deve ser concebida não apenas como um periódico "depositário de acontecimentos nos diversos processos e conjunturas", mas especialmente "como uma força ativa da história". ${ }^{8}$ Tal constatação não se dá ao léu, pois quando do surgimento de sua primeira de edição, uma espécie de manifesto-programa foi publicado e estabelecia os principais objetivos desse periódico. Vejamos:

Nossa revista tem uma finalidade precipua: tornar mais conhecida e melhor compreendida a vasta região do Centro-

${ }^{5}$ BARBOSA, M. História cultural da imprensa: Brasil, 1900-2000. Rio de Janeiro: Mauad Ed., 2007. p. 150.

${ }^{6}$ RIBEIRO, A. P. G. Imprensa e história no Rio de Janeiro dos anos 1950. Rio de Janeiro: e-papers, 2007. p. 14.

${ }^{7}$ BARBOSA, M. História cultural da imprensa: Brasil, 1900-2000. Rio de Janeiro: Mauad Ed., 2007. p. 153.

${ }^{8}$ CRUZ, H. F.; PEIXOTO, M. do R. da C. Na oficina do historiador: conversas sobre história e imprensa. Projeto História, São Paulo, n. 35, p. 235-270, 2007. p. 257. 
Oeste brasileiro, compreendida pelos Estados de Mato Grosso e Goiás.

De modo geral, entretanto, merecerão acolhimento, em nossas colunas, todos os fatos relacionados com os Estados que confinam com Mato Grosso, dada a identidade de interêsses que existe entre êles.

Não temos ligações com grupos políticos nem econômicos. Nossa atuação obedecerá a um roteiro superior, tendo em vista difundir a maior soma de conhecimentos sôbre as regiões brasileiras que estabelecemos como quadro natural de nossa atividade jornalistica.

Todos os problemas geoeconômicos que digam respeito aos Estados de Mato Grosso e de Goiás e aos Territórios do Guaporé e do Acre serão gradativamente examinados em nossas colunas, de modo que se esboce, através de uma honesta difusão de opiniões, uma solução adequada e justa para êles.

Particular interêsse merecerão de nossa parte os assuntos agropecuários, pois que nesse ramo de atividades se fundamenta a parcela mais ponderável da economia dos Estados do Centro-Oeste. $^{9}$

Como pode ser percebido, buscava-se estabelecer um "roteiro superior", que estava isento de "ligações com grupos politicos" e "econômicos". Pretendia-se "difundir conhecimentos" sobre o Oeste do país, na intenção de que fossem esboçadas e difundidas opiniões e soluções para os problemas daquela região. Esse manifesto não foi o único desenvolvido pela a revista. Em diversas oportunidades, foi publicado um tipo de programa de metas da Brasil-Oeste, em que constavam 10 tópicos especiais, cujo primeiro objetivo era fazer uma "colonização intensiva nos estados de Mato Grosso e Goiás". ${ }^{10}$

\footnotetext{
${ }^{9}$ Revista Brasil-Oeste, ano I, n. 1, jan. 1956, p. 2. Resolvemos manter a ortografia da época sem fazer qualquer alteração. Isso vale para todas as citações de documentos ou de bibliografia feitas neste artigo.

${ }^{10}$ Os outros nove objetivos eram: Fomento da cultura da seringueira nas regiões norte e noroeste de Mato Grosso; incremento da cafeicultura no leste e oeste de Mato Grosso e no sul de Goiás; fomento da triticultura nas áreas de Dourados, Itaporã, Maracaju, Bonito, Guia Lopes da Laguna e Terenos; fomento da lavoura de algodão nas áreas de Dourados, Rio Brilhante e Campo Grande; introdução de práticas modernas no criatório e incentivo à formação de planteis de gado leiteiro na "região" sulina de Mato Grosso; pesquisas e exploração do petróleo na zona pantaneira de Mato Grosso; expansão da rede ferroviária em direção a Cuiabá e
} 
Nesse sentido, pretendemos analisar alguns textos publicados por essa revista entre os anos de 1956 e 1961, e que enfatizaram a questão da colonização como uma das possibilidades encaradas pelo grupo dirigente da revista como ideal para o desenvolvimento do estado de Mato Grosso. Levando em consideração o fato de que não é possível contemplar todos os temas que foram debatidos no decorrer dos anos nas páginas da revista neste artigo, o foco na questão da colonização se dá por duas razões principais. A primeira reside no fato de que tal tema foi muito debatido na esfera política nos anos de 1950 e, conforme ressaltam alguns autores que se debruçaram a estudar sobre o assunto, ${ }^{11}$ essa década foi um período de capital importância para intensificar a colonização em Mato Grosso.

Em segundo lugar, porque também nas páginas da revista a colonização foi uma pauta muito debatida e inseparável das questões políticas e econômicas do estado. Assim, foi possivel perceber, ao recortar o periodo de 1956-1961, que, mais do que um debate sobre o desenvolvimento econômico do estado, incluindo aí a colonização, também havia uma intensa discussão política travada por meio das páginas da Brasil-Oeste. Essa discussão, por sua vez, ficava polarizada entre dois dos principais personagens politicos mato-grossenses daquele momento: Fernando Corrêa da Costa (União Democrática Nacional) e João Ponce de Arruda (Partido Social Democrático), ambos governadores do estado no interregno de tempo que compreende a década de 1950.

Essa disputa política - em meio a uma suposta mensagem de modernização e desenvolvimento em Mato Grosso

\footnotetext{
ligação, por estrada de ferro, da capital mato-grossense a Brasília; aproveitamento do potencial hidráulico da região da Bacia Paraná-Uruguai e a introdução de indústrias de abastecimento nos estados de Mato Grosso e Goiás.

11 MOREnO, G. Terra e poder em Mato Grosso: política e mecanismos de burla (1892-1992). Cuiabá: Entrelinhas/EdUFMT, 2007; LENHARO, A. A terra para quem nela não trabalha (a especulação com a terra no oeste brasileiro nos anos 50). Revista Brasileira de História, São Paulo, v. 6, n. 12, p. 47-64, 1986; VASCONCELOS, C. A. de. Colonização e especulação fundiária em Mato Grosso: a implantação da Colônia Várzea Alegre (1957-1970). 1986. 161f. Dissertação (Mestrado em História) - UNESP, Assis.
} 
- pode ser um indicativo das relações existentes entre o grupo que se aglutinou em torno da revista Brasil-Oeste e uma parcela dos políticos mato-grossenses. É bom dizer que, mesmo na década de 1950, a neutralidade na imprensa era um tema muito debatido pelo jornalismo, sobretudo no Rio de Janeiro e em São Paulo. É necessário, no entanto, ressaltar que o "aspecto político jamais desapareceu totalmente, exercendo um papel fundamental - estrutural - na dinâmica das empresas jornalísticas", mesmo quando avançaram no aspecto de "gestão e administração", uma vez que somente a publicidade e as vendas "não eram suficientes para garantir autonomia" 12 financeira. Por essa razão, é importante dizer que a imprensa nunca deixou totalmente de se alinhar politicamente, pois o "apoio a determinados grupos no poder ou na oposição era essencial para garantir a sobrevivência das empresas, fosse através de créditos, empréstimos, incentivos ou mesmo publicidade". ${ }^{13}$

Dito isso, faz-se necessário realizar agora uma contextualização sobre o processo de colonização em Mato Grosso nos anos de 1950, pois, conforme indica Tania Regina de Luca, os periódicos, polos em torno dos quais se reúnem e disciplinam forças de combate e intervenção no espaço público, oferecem oportunidades privilegiadas para explicitar e dotar a densidade dos embates em torno de projetos politicos que, longe de esgotarem-se em si mesmos, dialogam intensamente com os dilemas do seu tempo. ${ }^{14}$ Entender como tal questão foi objeto de disputas políticas nos permitirá compreender com maior clareza as questões debatidas na Brasil-Oeste.

\footnotetext{
${ }^{12}$ RIBEIRO, A. P. G. Jornalismo, literatura e política: a modernização da imprensa carioca nos anos 1950. Estudos Históricos - CPDOC/FGV, Rio de Janeiro, v. 31, p. 147-160, 2003. p. 156.

13 Ibidem.

${ }^{14}$ DE LUCA, T. R. Leituras, projetos e (re)vista(s)do Brasil (1916-1944). São Paulo: Editora UNESP, 2011. p. 2.
} 


\section{A colonização e a política no estado de Mato Grosso na década de 1950}

No período da década de 1950, no Brasil havia uma corrente de pensamento político (que tinha como seus maiores ícones Getúlio Vargas e Juscelino Kubitschek), que acreditava na necessidade de uma ocupação efetiva e imediata do Extremo-Oeste do país, pois o Oeste seria "a terra da Promissão, com grandes reservas de terras férteis", que substituiriam as "esgotadas e devastadas do Leste"15 do país. O início desse projeto se deu com a "Marcha para Oeste", que incentivava a ocupação das regiões "vazias" 16 do Brasil, sob a intenção de "nacionalizar" as fronteiras e fortalecer a ideia de "construção da Nação" por todos os brasileiros, ${ }^{17}$ e que acabou desencadeando a criação dos projetos de Colônias Agrícolas Nacionais, tais como a de Goiás e a de Dourados. ${ }^{18}$

Nesse sentido, o governo Vargas visava "alargar" o espaço nacional e estender a produção para localidades "distantes", como Amazonas, Goiás e Mato Grosso. Em resumo, havia uma política de colonização dirigida pelo Estado a fim de fazer com que trabalhadores de outras regiões pudessem se estabelecer em áreas ainda "pouco" habitadas e, para isso, as Colônias Agrícolas foram pensadas e colocadas em prática.

${ }^{15}$ RODRIGUES, J. H. Aspirações nacionais: interpretação histórico-politica. 4. ed. Rio de Janeiro: Civilização Brasileira, 1970. p. 84. Os grifos são nossos.

${ }^{16}$ É importante ressaltar que a região de Mato Grosso era ocupada por povos indigenas muito antes da "Marcha para Oeste" varguista. Nesse sentido, povoar as "regiões vazias", naquela altura, significava que se buscava ajustar ali uma população "não indigena", ou, como ressalta Alcir Lenharo, assentar "trabalhadores disciplinados e produtivos", mostrando toda a carga de exclusão que tal empreendimento exerceu. O mesmo autor, no entanto, informa que além dos indígenas, outros segmentos da sociedade já estavam ali presentes. Nas palavras do autor, "os espaços vazios não se encontravam tão vazios assim". Sobre o tema, cf.: LENHARO, A. Colonização e trabalho no Brasil: Amazônia, Nordeste e Centro-Oeste. Os anos 30. 2. ed. Campinas: Ed. Unicamp, 1986.

17 OLIVEIRA, B. C. A política de colonização do Estado Novo em Mato Grosso (1937 a 1945). 243f. Dissertação (Mestrado em História) - FCL/UNESP, Assis, 1999. p. 88.

${ }^{18}$ A Colônia Agrícola de Goiás foi criada conforme o Decreto-Lei no 3.059, em 14 de fevereiro de 1941. A criação da Colônia Agrícola Nacional de Dourados ocorreu somente em 1943 pelo Decreto-Lei $n^{\circ}$ 5.941, mas foi demarcada no ano de 1948, já sob a gestão presidencial de Eurico Gaspar Dutra. 
Ali, o Governo distribuía terras gratuitamente para quem quisesse nelas se estabelecer. ${ }^{19}$

É importante dizer que, ainda no ano de 1950, o Norte e o Centro-Oeste do Brasil abrangiam em conjunto $64,1 \%$ da superficie nacional, contudo, aglomeravam apenas $6,86 \%$ da população. No ano de 1957, a região central permanecia com a baixíssima porcentagem de $3,57 \%$ da população brasileira. Então, os temas envolvendo a colonização e ocupação das áreas "desocupadas" estiveram na pauta política nacional, especialmente, o caso mato-grossense. ${ }^{20}$

Como ressalta Claudio Vasconcelos, em estudo específico sobre a colonização de Mato Grosso em meados do século $\mathrm{XX}$,

[...] colocou-se um problema ao governo brasileiro, qual seja, a necessidade de uma definição diante da grande variedade de questões relativas ao campo, de maneira a exigir uma política agrária adequada. Entre as múltiplas facetas desse mesmo problema, a existência de regiões contendo espaços vazios, isto é, não ocupados pelo capital, contrapondo-se a regiões mais densamente ocupadas, motivou o debate que percorreu a década de 50 sobre a necessidade de se promover a ocupação efetiva daquelas áreas. O desenvolvimento desse debate acabou por envolver os governos dos Estados, dentro dos quais existiam aqueles vazios. Em consonância com a política do governo federal houve a necessidade do desenvolvimento de política dos Estados dentro da situação a ser objeto no sentido do desenvolvimento de uma política de colonização dirigida. ${ }^{21}$

No estado de Mato Grosso, desde o governo de Arnaldo Estevão de Figueiredo (PSD, 1947-1950), ${ }^{22}$ intensificava-se

\footnotetext{
${ }^{19}$ LENHARO, A. A terra para quem nela não trabalha (a especulação com a terra no oeste brasileiro nos anos 50). Revista Brasileira de História, São Paulo, v. 6, n. 12 , p. 47-64. 1986a. p. 50.

${ }^{20}$ RODRIGUES, J. H. Aspirações nacionais: interpretação histórico-política. 4. ed. Rio de Janeiro: Civilização Brasileira, 1970. p. 182.

21 VASCONCELOS, C. A. de. Colonização e especulação fundiária em Mato Grosso: a implantação da Colônia Várzea Alegre (1957-1970). p. 20-21.

${ }^{22}$ Arnaldo Estevão de Figueiredo foi prefeito de Campo Grande, hoje capital do estado de Mato Grosso do Sul, e elegeu-se governador do antigo estado de Mato Grosso em 1947, na legenda da aliança entre o Partido Social Democrático (PSD) e o Partido Trabalhista Brasileiro (PTB).
} 
um plano de reorganização da colonização para acelerar o "desenvolvimento" do estado, que havia sido iniciado durante o governo Vargas no já mencionado projeto "Marcha para Oeste". Assim, a partir da posse de Figueiredo, houve um forte discurso contrário à política governamental colonização. ${ }^{23}$ O projeto estatal de colonização lançado pelo Estado Novo foi reformulado pela associação entre o poder público e as companhias privadas e, tal como afirma Alcir Lenharo, "após a queda de Vargas, quando o intervencionismo estatal foi afastado [...] o tratamento da terra como mercadoria implementou a expansão especulativa da colonização do país". ${ }^{24}$ Nesse sentido, conforme ressalta Gislaene Moreno, Figueiredo planejou uma "ampla estratégia de ocupação do oeste brasileiro". Esse modelo "consistia na implantação de projetos oficiais de colonização, por meio de empresas particulares, o qual se revelou um projeto lucrativo, tanto em termos econômicos quanto partidário e eleitoral". ${ }^{25}$

Vale lembrar que o mandato de Arnaldo Estevão de Figueiredo foi concomitante ao fim do período presidencial de Eurico Gaspar Dutra e o início do segundo governo de Getúlio Vargas. Nesse momento, já havia no Brasil uma forte discussão que ficava tensionada entre aqueles que defendiam um governo intervencionista e um bloco mais próximo dos interesses financeiros e comerciais vinculados ao comércio exterior. Tratava-se, na verdade, de um periodo de transição. Mais adiante, no governo de Juscelino Kubitschek, torna-se mais perceptivel uma "politica orientada para o desenvolvimento econômico dependente, ou associado aos mercados estrangeiros". ${ }^{26}$

\footnotetext{
${ }^{23}$ LENHARO, A. A terra para quem nela não trabalha (a especulação com a terra no oeste brasileiro nos anos 50). Revista Brasileira de História, São Paulo, v. 6, n. 12, p. 47-64. 1986a. p. 51.

${ }^{24}$ LENHARO, A. Colonização e trabalho no Brasil: Amazônia, Nordeste e Centro-Oeste. Os anos 30. 2. ed. Campinas: Ed. Unicamp, 1986b, p. 46.

${ }^{25}$ MOREnO, G. Terra e Poder em Mato Grosso: politica e mecanismos de burla (1892-1992). Cuiabá: Entrelinhas/EdUFMT, 2007, p. 103. Os grifos são nossos.

${ }^{26}$ SCHALLENBERGER, E.; SCHNEIDER, I. E. Fronteiras agricolas e desenvolvimento territorial - ações de governo e dinâmica do capital. Sociologias, Porto Alegre, ano 12, n. 25, set/dez. 2010, p. 202-222, p. 210.
} 
A partir de então, no caso de Mato Grosso, a cada novo governo que iniciava um mandato, uma questão era colocada em pauta: a legislação de terras "era sempre" obsoleta para o período, havendo, nesse sentido, urgência em modificá-la para facilitar o processo de colonização associado à iniciativa privada. Na opinião de Figueiredo, a legislação "se encontrava divorciada da realidade", ${ }^{27}$ pois, segundo Gislaene Moreno (comentando as mensagens governamentais desse governador), a modalidade "antiga" de colonizar terras "cerceava os grandes empreendimentos particulares, capazes de promover a efetiva ocupação do Estado em moldes empresariais". ${ }^{28}$ Daí, buscava-se solucionar os problemas e os entraves que dificultavam a aquisição de terras por empresas particulares.

Assim, em 1949, foi promulgado o novo Código de Terras de Mato Grosso, pela Lei $\mathrm{n}^{\circ}$ 336, de 6 de dezembro de 1949, em que se "criou uma comissão especial para proceder a discriminação das terras devolutas para vendas ou para estabelecimento de núcleos coloniais". ${ }^{29}$ Esse novo código esteve pautado em "dois aspectos fundamentais, regulamentação da propriedade e colonização", ${ }^{30}$ sendo modificado diversas vezes depois, demonstrando a desordem que imperava no que concerne às questões envolvendo as terras da região e sua legislação.

Dentre os grandes problemas observados pelo governador Figueiredo e utilizados como argumento para a "liberalização" dos negócios, envolvendo as terras do Estado, estava o fato de que "o poder público [federal] limitara-se a reservar terras sem ter estabelecido colônias" e, nesse sentido, a iniciativa privada ficava prejudicada, uma vez que "ficariam impossibilitadas de demarcar os seus lotes, pois o Estado não demarcara anteriormente suas reservas", fazendo

${ }_{27}$ Mensagens Governamentais do Governador Arnaldo Estevão de Figueiredo, Cuiabá, 1948.

${ }^{28}$ MOReno, G. Terra e Poder em Mato Grosso: politica e mecanismos de burla (1892-1992). Cuiabá: Entrelinhas/EdUFMT, 2007. p. 103. Os grifos são nossos.

29 VASCONCELOS, C. A. de. Colonização e especulação fundiária em Mato Grosso: a implantação da Colônia Várzea Alegre (1957-1970). p. 24.

${ }^{30}$ MOREnO, G. Terra e Poder em Mato Grosso: politica e mecanismos de burla (1892-1992). Cuiabá: Entrelinhas/EdUFMT, 2007. p. 106. Os grifos são nossos. 
alusão à Colônia Agrícola de Dourados que teve suas terras "demarcadas somente depois de 1948". ${ }^{31}$

No governo seguinte, foi acentuado o plano de colonização privada no Mato Grosso. Conforme ressalta Gardin, no início dos anos de 1950, quando começava o seu primeiro mandato (1951-1956), o governador Fernando Corrêa da Costa (UDN) apoiou-se em "em três eixos de ação para o desenvolvimento do estado: energia, transporte e povoamento". Para fazer progredir o estado, traçou um planejamento para a energia, que consistia na "necessidade de estudarem-se primeiramente os saltos de Urubupungá e Sete Quedas, no rio Paraná, para a produção de energia elétrica, além da desobstrução desses obstáculos para a livre navegação". ${ }^{32} \mathrm{Em}$ relação ao transporte, propôs, dentre outras coisas, "a indicação do prolongamento das Estradas de Ferro Sorocabana e Araraquarense ao Mato Grosso". Por último, e especialmente importante para a presente análise, o governou tomou a decisão de "povoar-se o Mato Grosso por 'colonização racional' [entenda-se, por empreendimento empresarial]". ${ }^{33}$

Nesse sentido, foi sob o mandato de Fernando Corrêa da Costa que a politica de colonização particular foi intensificada e uma das primeiras medidas tomadas pelo então novo governador, tal como seu antecessor, foi introduzir modificações no Código de Terras de 1949. Nas palavras de Moreno, "de acordo com a politica federal de ocupação dos 'espaços vazios', retomada por Vargas (1951-1954), [Corrêa da Costa] implementou no Estado a política de colonização, entregando esta tarefa a empresas particulares de colonização". ${ }^{34}$ Isso significa dizer que o governo estadual era o responsável pela tarefa de colonizar, seja pela colonização oficial, em que o estado era

\footnotetext{
${ }^{31}$ LENHARO, A. Colonização e trabalho no Brasil: Amazônia, Nordeste e Centro-Oeste. Os anos 30. 2. ed. Campinas: Ed. Unicamp, 1986a. p. 51.

32 GARDIN, C. A Comissão Interestadual da Bacia Paraná-Uruguai no planejamento regional brasileiro (1951-1972). Dourados: Ed. UFGD, 2009. p. 116.

${ }^{33}$ Ibidem.

${ }^{34}$ MOREno, G. Terra e Poder em Mato Grosso: politica e mecanismos de burla (1892-1992). Cuiabá: Entrelinhas/EdUFMT, 2007. p. 113.
} 
o responsável, ou por intermédio de empresas colonizadoras particulares. ${ }^{35}$

A implementação da Lei $\mathrm{n}^{\circ} 461$, de 10 de dezembro de 1951, autorizava "o governo a contratar, com terceiros, a colonização de áreas para este fim reservadas", uma vez que se buscava "fixar um [maior] contingente populacional" que, por sua vez, aumentaria "o mercado consumidor, ampliando assim a receita do Estado e o volume da produção". ${ }^{36}$ Para que tal empreendimento obtivesse sucesso, era imprescindivel a ajuda da iniciativa privada. Mais uma vez, nas palavras do autor,

Para a execução desse projeto, o governo do Estado colocou, à disposição de empresas colonizadoras, grande parte de seu território para que as mesmas, através de Contrato de Colonização, organizassem os núcleos coloniais e efetuassem a venda da terra. O governo fez esse tipo de contrato, com particulares, individualmente, ou com empresas organizadas, desde que os mesmos assumissem certas condições específicas relacionadas às disposições de leis federais e estaduais. ${ }^{37}$

Em poucas palavras, o Estado fazia os contratos com as colonizadoras de terras, que ficavam encarregadas de abrir estradas, medir as áreas, planejar o loteamento, efetuar benfeitorias sobre as "terras nuas", enfim, fazer com que as áreas concedidas tivessem o mínimo de requisitos para comportar uma determinada infraestrutura. Feito todo esse processo, em tese, sob a vigilância do Estado, iniciava-se a venda dos lotes para os colonos (por parte das colonizadoras) que, depois de vendidos, seriam titulados pelo governo de Mato Grosso, diretamente para aqueles que tinham efetuado a compra junto às colonizadoras. ${ }^{38}$

\footnotetext{
${ }^{35}$ NAGLIS, S. G. B. "Marquei aquele lugar com o suor do meu rosto": os colonos da Colônia Agrícola Nacional de Dourados - CAND (1943-1960). 118f. Dissertação (Mestrado em História) - Programa de Pós-Graduação em História da Universidade Federal da Grande Dourados, Dourados, 2007. p. 32.

36 VASCONCELOS, C. A. de. Colonização e especulação fundiária em Mato Grosso: a implantação da Colônia Várzea Alegre (1957-1970). p. 23-24. Os grifos são nossos.

${ }^{37}$ Ibidem.

38 Informações obtidas através das Mensagens Governamentais do Governador Fernando Corrêa da Costa (1952-1955).
} 
O governador Fernando Corrêa da Costa, na intenção de convencer os mato-grossenses de que havia a necessidade de uma intensificada colonização no estado, empenhava-se naquele projeto. Nas Mensagens Governamentais de 1953, nota-se o seu esforço em dar créditos aos colonizadores de terras do estado de Mato Grosso, atribuindo a eles, inclusive, o ideal do bandeirantismo, idealizando-os como os "bravos desbravadores dos sertões!" Essa associação foi feita no discurso proferido à Assembleia Legislativa e que pode ser conferido no seguinte trecho:

[...] presenciamos um fenômeno inédito: a procura de terras novas e baratas, não apenas por pequenos lavradores, mas por capitalistas. Há uma corrida em busca de solos virgens que, em breve, significarão café, borracha, cereais, os produtos valorizados desta quadra e que irão dar outra construção econômica a esta parte da nação. O território mato-grossense constitui, de fato, um convite para uma deslocação de fronteira, à espera de novos bandeirantes dotados de espirito de iniciativa aparelhados de capitais e métodos modernos. ${ }^{39}$

Os capitalistas eram os "novos bandeirantes" que sabiam o que era necessário para fazer progredir "esta parte da nação". Em resumo, o estado de São Paulo devia ser o modelo a ser seguido. No trecho a seguir, fica nítido esse anseio por parte do governador, ao fazer referência aos colonizadores como "novos pioneiros, [que] já penetraram, [e] se instalam na nossa terra e começam a trabalhar, procurando anular os séculos de evolução que separam S. Paulo de Mato-Grosso[...]". ${ }^{40}$

Percebe-se que o clima de otimismo fazia-se presente naquela gestão, sobretudo se for levado em consideração o sucesso nas vendas de terras, influenciando diretamente no aumento de arrecadação de recursos financeiros por parte do estado de Mato Grosso, que já vinha numa crescente desde o ano de 1952. O governador Fernando Corrêa da Costa orgulhava-se desse suposto sucesso e enfatizava que finalmente

\footnotetext{
${ }^{39}$ Mensagens Governamentais do Governador Fernando Corrêa da Costa, 1953, p. 4. Os grifos são nossos.

${ }^{40}$ Mensagens Governamentais do Governador Fernando Corrêa da Costa, 1953, p. 4. Os grifos são nossos.
} 
"as vistas do Brasil litorâneo" se volviam para o interior do país. Dizia ele:

Rompido o véu do desconhecimento em que jaziamos, mercê da distância que a falta de vias de comunicação avultava, verificamos que as vistas do Brasil litorâneo se volvem para cá. A procura de glebas férteis está impelindo uma apreciável corrente imigratória que os quase 12.000 requerimentos de pretendentes a terras devolutas, em andamento nas Repartições competentes, dão bem a característica da realidade vista sem as lentes de Pangloss. ${ }^{41}$

Apesar do sucesso no aumento de arrecadação adquiridas por meio das vendas de terras, Gislaene Moreno constata que havia uma:

[...] violenta especulação com a terra no governo Fernando Corrêa da Costa, sobretudo no ano pré-eleitoral, embora não tivesse poupado críticas ao seu antecessor e justificasse seus atos como necessários ao atendimento do "inusitado fluxo de pessoas e capitais" que afluiam para Mato Grosso. Ou seja, isto significava "um incentivo à produção", que tem na exploração da terra a sua base máxima, para a vitalização da economia do Estado, que na época contava com pouco mais de 400.000 habitantes. ${ }^{42}$

\section{Conforme ressalta Suzana Naglis,}

É importante observar que a venda de terras devolutas não só tinha o objetivo de promover a colonização, o povoamento, e aumentar a produção agrícola e conseqüentemente o desenvolvimento econômico. As terras devolutas foram usadas em favor das negociatas politicas, resultado de um aparato estatal corrupto e incipiente que não coibia as irregularidades na venda de terras do estado de Mato Grosso. ${ }^{43}$

\footnotetext{
${ }^{41}$ Mensagens Governamentais do Governador Fernando Corrêa da Costa, 1952, p. 4. Os grifos são nossos.

${ }^{42}$ MOREnO, G. Terra e Poder em Mato Grosso: política e mecanismos de burla (1892-1992). Cuiabá: Entrelinhas/EdUFMT, 2007. p. 115.

${ }^{43}$ NAGLIS, S. G. B. "Marquei aquele lugar com o suor do meu rosto": os colonos da Colônia Agrícola Nacional de Dourados - CAND (1943-1960). 118f. Dissertação (Mestrado em História) - Programa de Pós-Graduação em História da Universidade Federal da Grande Dourados, Dourados, 2007. p. 33.
} 
O governo de Mato Grosso justificava que "não dispondo o Estado de recursos financeiros capazes de manterem o serviço de colonização, achamos que o povoamento das nossas [...] terras, em pleno desconhecido, somente se poderá realizar mediante o concurso da iniciativa privada". ${ }^{44}$ Nas Mensagens Governamentais do ano de 1954, dizia o governador Fernando Corrêa da Costa,

[...] é a colaboração da iniciativa privada com a estatal objetivando uma das tarefas mais alvissareiras, que é a de tornar produtivas regiões até agora desconhecidas. Não dispondo o Estado de recursos para essa obra, não há como repelir a cooperação de empresas credenciadas para realizá-las. ${ }^{45}$

No entanto, muitas das "obrigações" a que se comprometiam as empresas não foram devidamente respeitadas, e diversas irregularidades foram encontradas no cumprimento das cláusulas dos contratos de colonização de terras. Iniciava-se, então, um escândalo na gestão de Fernando Corrêa da Costa, pois foi acusado de ter vendido terras acima da área permitida pela Constituição Federal.

Para elucidar o caso, trata-se da ocasião em que 22 empresas firmaram contrato com o governo estadual, sob a gestão de Fernando Corrêa da Costa, equivalentes a uma área próxima de 3,5 milhões de hectares em Mato Grosso para colonização. Gislaene Moreno informa que cada uma delas adquiriu em média "200.000 hectares [...] cujos lotes de 10.000 hectares eram contíguos e de pessoas de um mesmo grupo", o que por si só "violava o prescrito na Constituição Federal (1948) que vedava a alienação de áreas superiores a 10.000 hectares, sem prévia autorização do Senado". ${ }^{46}$ De modo semelhante, Alcir Lenharo ressalta que:

[...] a ilegalidade das concessões incidia sobre as determinações do artigo 156 da Constituição Federal de 1948 [...] Acresce

\footnotetext{
${ }^{44}$ Mensagens Governamentais do Governador Fernando Corrêa da Costa, 1954, p. 78-79.

${ }^{45}$ Mensagens Governamentais do Governador Fernando Corrêa da Costa, 1954, p. 6.

${ }^{46}$ MOREnO, G. Terra e Poder em Mato Grosso: politica e mecanismos de burla (1892-1992). Cuiabá: Entrelinhas/EdUFMT, 2007. p. 116.
} 
terem sido as enormes concessões todas desviadas para posterior revenda especulativa de lotes menores. ${ }^{47}$

No entanto, os títulos definitivos eram expedidos pelo estado. Gislaene Moreno faz referência à defesa feita pelo governo Fernando Corrêa da Costa, em que esse último afirmava que "a titulação de terras aos colonos cabia ao Estado, sendo proibida a aquisição de lotes superiores a 2.000 hectares". ${ }^{48}$ Fausto Vieira de Campos, em seu livro Retrato de Mato Grosso, também explica com clareza qual era o procedimento em relação a essa questão. Dizia o autor:

As glebas contratadas para colonização não são transferidas ao particular ou à emprêsa, nem oneradas por compromissos outros além dos estatuídos formalmente nos contratos. Estes dispõem obrigações definidas, cujo cumprimento se exige antes que as glebas, depois de loteadas, sejam objeto de transações com terceiros [...] Cumpridas [as] exigências preliminares admite-se a revenda dos lotes, à vista ou a prestação, mediante outorga de documento hábil que se substitui, no final do compromisso, por título definitivo de propriedade expedido pelo Govêrno do Estado. ${ }^{49}$

Aproveitando-se desse clima tenso, no que diz respeito às vendas e contratos com as colonizadoras de terras em Mato Grosso, quando João Ponce de Arruda assumiu o governo (1956), ele fez duras críticas ao governo de Fernando Corrêa da Costa, utilizando-se dos escândalos envolvendo o Departamento de Terras e Colonização de Mato Grosso para fundamentá-las:

[...] no momento, este Departamento, o setor principal das atividades afeta à Secretaria da Agricultura, cabendo-lhe processar até [o] final, os pedidos de compra de terras devolutas [...] do Estado, atividade que tanta celeuma deu causa no último período governamental, quando a aquisição de terras públicas por particulares se transformara numa desenfreada

\footnotetext{
${ }^{47}$ LENHARO, A. Colonização e trabalho no Brasil: Amazônia, Nordeste e Centro-Oeste. Os anos 30. 2. ed. Campinas: Ed. Unicamp, 1986a. p. 56.

${ }^{48}$ MOREnO, G. Terra e Poder em Mato Grosso: política e mecanismos de burla (1892-1992). Cuiabá: Entrelinhas/EdUFMT, 2007. p. 116.

${ }^{49}$ CAMPOS, F. V. de. Retrato de Mato Grosso. São Paulo: Sem editora, 1955, p. 93.
} 
e inescrupulosa atividade de lucros fáceis e de aglutinação de fortuna rápida, fazendo surgir conflitos de interesses os mais variados, que acabariam muitas vezes, em violações de direitos os mais legitimos, em beneficios de traficantes de terras ou de apaniguados políticos, e quase sempre com sacrificio do verdadeiro e humilde colono que é o elemento que Mato Grosso verdadeiramente carece.

Enquanto aos pequenos se fechavam as portas do D.T.C. através dificuldades de tôda ordem, aos seus dirigentes e a terceiros apadrinhados de dirigentes ou a estes associados, se abriam elas numa exibição inusitada, em que firmas nem sempre honestas, transformavam as dependências do D.T.C. em seus escritórios particulares, muitas vezes dirigidos por servidores ali lotados adredemente $[\ldots]^{50}$

As críticas foram ácidas e diretas. Além disso, mais uma vez um governante que assumia o poder no estado de Mato Grosso "encontrava" irregularidades no Departamento de Terras e Colonização. Como ressalta Gislaene Moreno, "a crítica do governador [João Ponce de Arruda] em nada diferencia da que fizera o próprio Fernando Corrêa da Costa ao seu antecessor, em 1951". ${ }^{51}$ Ainda nas palavras da autora, o governo Fernando Corrêa da Costa foi acusado de "facilitar" esses contratos, especialmente, porque tais acordos teriam sido feitos em anos pré-eleitorais, ${ }^{52}$ o que significa dizer que, no final das contas, teria sido uma jogada "político-eleitoreira", intentando angariar apoio desse setor do segmento privado nas eleições que estavam por vir, em 1955, pois evidentemente a UDN planejava fazer um sucessor.

Em mensagem enviada por João Ponce de Arruda à Assembleia Legislativa, ele acusava a "falta de idoneidade das pessoas favorecidas com a concessão de terras" e uma inversão daquilo que devia ser a Lei $n^{\circ} 461$, de dezembro de 1951, que autorizava o governo do estado a contratar empresas particulares para a colonização de parte das áreas reservadas para esse fim. Diz o governador que essa ideia era "de certa

\footnotetext{
${ }^{50}$ Mensagens Governamentais do Governador João Ponce de Arruda, 1956, p. 67.

${ }^{51}$ MORENO, G. Terra e Poder em Mato Grosso: política e mecanismos de burla (1892-1992). Cuiabá: Entrelinhas/EdUFMT, 2007. p. 122

${ }^{52}$ Ibidem, p. 116.
} 
forma aceitável", desde que "honestamente concretizada" e que certamente traria "proveitos sensiveis" para a região, uma vez que o estado não podia "fazer frente por si mesmo à colonização de vulto, a forma que creara a lei de 1951, seria, talvez capaz de levar-nos à solução do problema". ${ }^{53}$

Sabendo disso, o novo governo de Mato Grosso resolveu tomar algumas medidas. Nesse sentido, parafraseando Gislaene Moreno, o governador João Ponce de Arruda manteve uma postura de cautela no início de seu mandato e, em princípio, não confirmou as concessões expedidas pelo governo anterior, o que lhe valera duras criticas por parte dos defensores das companhias particulares. ${ }^{54}$ Foram sustadas novas concessões e alienações até o ano de 1957, período em que o Departamento de Terras funcionou apenas internamente ${ }^{55}$ a fim de regularizar os problemas ali existentes.

Desse modo, os contratos envolvendo as 22 empresas colonizadoras foram colocados sub judice pelo Senado Federal por suposta fraude à Constituição. João Ponce de Arruda fez questão de mencionar isso nas suas primeiras Mensagens Governamentais, proferidas em junho de 1956 na Assembleia Legislativa. Disse o governador,

Em sua maioria, com algumas exceções, as Colonizadoras vendem suas áreas por alto preço, não beneficiando de maneira alguma as glebas, de acôrdo com as obrigações contratuais (demarcação, estrada de penetração, etc.), o que vem causando descrédito não só às emprêsas como ao Estado.

A legalidade dessas concessões foi objeto de Inquérito pelo Senado da República, aguardando o Govêrno Estadual a decisão final sôbre a matéria para traçar a orientação a seguir. ${ }^{56}$

É válido dizer que o Requerimento para a abertura de Comissão de Inquérito no Senado, para investigar as alienações de terras no estado de Mato Grosso, foi apresentado pelo

${ }^{53}$ Mensagens Governamentais do Governador João Ponce de Arruda, 1956, p. $72-$ 73.

${ }^{54}$ MOREnO, G. Terra e Poder em Mato Grosso: politica e mecanismos de burla (1892-1992). Cuiabá: Entrelinhas/EdUFMT, 2007. p. 122.

${ }^{55}$ Ibidem, p. 123.

${ }^{56}$ Mensagens Governamentais do Governador João Ponce de Arruda, 1956, p. 119. 
senador mato-grossense Heitor Medeiros (PSD), no dia 01 de julho de 1955. Ele fazia a seguinte solicitação: "a criação de uma Comissão de Inquérito a fim de apurar as alienações e concessões de terras feitas pelo Governo do Estado de Mato Grosso sem a prévia autorização do Senado". ${ }^{57}$

No entanto, ainda hoje, a historiografia não deu conta de esclarecer os pormenores que dizem respeito a esse inquérito que tramitou no Senado. Na bibliografia consultada, especialmente em Alcir Lenharo e Gislaene Moreno, ambos os autores indicam que a Comissão Parlamentar de Inquérito foi criada, a partir da denúncia de membros do PSD mato-grossense, para investigar a titulação de terras que extrapolavam a área de 10.000 hectares permitida. Porém, Moreno, por exemplo, pautada nas Mensagens Governamentais de João Ponce de Arruda, do ano de 1959, indica que os contratos colocados sub judice "foram cancelados por outras irregularidades contratuais, referentes à demarcação dos lotes, o melhoramento da infra-estrutura daquelas áreas". ${ }^{58}$ Não há menção alguma sobre a venda de áreas acima de 10.000 hectares.

O que pretendemos dizer é que as denúncias lançadas pelos partidários do PSD e também pelas páginas da imprensa (em relação à suposta titulação de terras que excediam o limite de 10.000 hectares) alimentaram um tipo de "verdade" que a própria historiografia repercutiu sem debater atentamente a questão. Nesse sentido, os estudos que se debruçaram a discutir tal tema acabaram absorvendo essa ideia, pois provavelmente não foi possivel consultar a documentação do inquérito feito no Senado e nem os contratos de terras feitos pelo governo Fernando Corrêa da Costa.

Esse é um sinal de que o espinhoso tema dos contratos de colonização do governo Fernando Corrêa da Costa ainda carece de pesquisa mais aprofundada, pois, se for levado em consideração o resultado da investigação feita pelo Senado, apontado pelos estudos de Alcir Lenharo e Gislaene Moreno,

\footnotetext{
${ }^{57}$ Requerimento $\mathrm{n}^{\circ} 294$, de 2 de julho do ano de 1955. Arquivo Senado Federal. Publicado em 02/07/1955 no Diário do Congresso Nacional, seção II, p. 1592.

${ }^{58}$ MORENO, G. Terra e Poder em Mato Grosso: política e mecanismos de burla (1892-1992). Cuiabá: Entrelinhas/EdUFMT, 2007. p. 123. 
ficou constatado que "das 22 empresas colonizadoras, que já estavam de posse das áreas cedidas para colonização, 19 tiveram seus contratos registrados no Tribunal de Contas", 59 porém, somente cinco delas "cumpriram a cláusula contratual referente ao levantamento total ou em parcelas da área disponibilizada". ${ }^{60}$

Não foi possível descobrir se o problema era, de fato, na concessão e na suposta venda de terras acima da área estipulada pelo já referido artigo 156 da Constituição de 1948, uma vez que esse não é o nosso objetivo principal. Não pretendemos dizer, no entanto, que não existiram irregularidades. Conforme já foi possivel citar, ficou comprovado que houve um descumprimento nas cláusulas contratuais por parte de diversas companhias, que não faziam a efetiva melhora em termos de infraestrutura das áreas que deviam ser exploradas, além da provável especulação e favorecimentos políticos.

No entanto, em diversas vezes, nas Mensagens Governamentais, Fernando Corrêa da Costa enfatizava explicitamente que os lotes finais, titulados pelo estado deviam ter no máximo a extensão de 2.000 hectares. A questão que se apresenta é a seguinte: teria sido o governador tão ingênuo em afirmar diversas vezes que não alienava terras acima de 10.000 hectares frente aos seus opositores na Assembleia Legislativa de Mato Grosso, e mesmo assim teria ele cometido o grave erro de titulá-las com áreas acima do permitido pela Lei? Creio os estudiosos precisam ir a fundo nos documentos da época, fazer a análise crítica deles, para que se possa ter uma resposta mais satisfatória a respeito.

De qualquer modo, quando apresentou o resultado da investigação feita pelo Senado à Assembleia Legislativa, no ano de 1959, o governador Ponce de Arruda tomou a atitude de validar a situação de algumas empresas inadimplentes, assumindo "o compromisso de regularizar a venda das terras, com base no compromisso de compra e venda já firmado entre os contratantes. O restante das terras deveria se reverter ao

\footnotetext{
${ }^{59}$ Ibidem. Os grifos são nossos.

${ }^{60}$ Ibidem. Os grifos são nossos.
} 
patrimônio do estado e ser vendido como terras devolutas". ${ }^{61}$ Nesse sentido, o Departamento de Assistência Técnica (D.A.T) entrou em entendimento com as cinco empresas que haviam pelo menos iniciado o processo de demarcação dos lotes, propondo-lhes:

[...] a fim de regularizar a situação daqueles que com elas haviam firmado contratos, a expedição dos títulos definitivos correspondentes a cada contrato, obrigando-se as emprêsas a requerer por compra ao Estado, o restante da área. Êsse critério, foi aceito pelas referidas Colonizadoras. ${ }^{62}$

Isso significa dizer que houve um recuo no plano de colonização associada entre o estado e a iniciativa privada, uma vez que, a partir daquele momento, as colonizadoras deviam tomar a iniciativa de colonizar por conta própria, sem a participação e fiscalização do poder público estadual. Elas deviam requerer, mediante compra direta, e não mais com contrato de colonização, as glebas de terras. O plano de colonização em terras públicas, desenvolvido no governo anterior, segundo Claudio Vasconcelos, foi "abandonado formalmente para induzir a venda das terras já comprometidas por contratos, contratos não cumpridos como prescrevia a lei. A iniciativa de colonização será, a partir desse momento, não mais do governo, mas de particulares". ${ }^{63}$

Como o governo estadual precisou de dois anos para regularizar as questões envolvendo as terras e colonização, o número de vendas de títulos diminuiu consideravelmente em relação ao governo predecessor. Nesse sentido, houve um decréscimo nas transações efetuadas pelo estado de Mato Grosso, apesar de ter arrecadado mais para os cofres públicos, resultado do aumento dos preços das terras.

Entre o período que compreende os anos de 1956-1961, sob o mandato de João Ponce de Arruda, o estado de Mato Grosso arrecadou a quantia de Cr\$198.154.056,40, na venda

\footnotetext{
${ }^{61}$ MORENO, G. Terra e Poder em Mato Grosso: politica e mecanismos de burla (1892-1992). Cuiabá: Entrelinhas/EdUFMT, 2007. p. 123.

${ }^{62}$ Mensagens Governamentais do Governador João Ponce de Arruda, 1959, p. 172.

63 VASCONCELOS, C. A. de. Colonização e especulação fundiária em Mato Grosso: a implantação da Colônia Várzea Alegre (1957-1970). p. 32.
} 
de um total de 5.577 títulos definitivos ou provisórios, pertinentes à área de $21.970 .259,17$ ha de terra, tendo uma média de $3.939,44$ ha cada propriedade. ${ }^{64} \mathrm{O}$ fato é que, mesmo que aparentemente tentando diminuir as irregularidades envolvendo as terras de Mato Grosso, o governo João Ponce de Arruda não ficou imune a elas, pois,

Embora a natureza do discurso do governador [...] fosse de denúncias à administração anterior e adotasse, ao mesmo tempo, uma postura mais reservada às possibilidades de manipulação no comércio de terras, tudo indica que o seu governo não ficou imune à especulação fundiária ligada aos interesses partidários. ${ }^{65}$

No mesmo sentido, Alcir Lenharo ressalta que:

Se o governador João Ponce de Arruda assume uma postura reservada quanto às possibilidades de manipulação no comércio de terras [...] sua coligação política (PSD/PTB) também acabaria se utilizando desses negócios como meio de angariar recursos para a sustentação do respectivo grupo político-partidário. ${ }^{66}$

Anos mais tarde, em 1962, Arruda foi acusado de ser um dos acionistas de uma empresa chamada Companhia Imobiliária do Vale do Araguaia, que teria tido inúmeras vantagens no processo de aquisição de terras devolutas em Mato Grosso. ${ }^{67}$ Em resumo, a década de 1950 foi um período em que os que mais lucraram "foram os negociantes de terras e os grandes empresários, pois só eles poderiam cumprir com os requisitos básicos exigidos pelo governo para a aquisição de terras para a colonização". ${ }^{68}$

\footnotetext{
${ }^{64}$ Informações retiradas de tabela elaborada por: MORENO, G. Terra e Poder em Mato Grosso: política e mecanismos de burla (1892-1992). Cuiabá: Entrelinhas/ EdUFMT, 2007. p. 124.

${ }^{65}$ Ibidem, p. 126.

${ }^{66}$ LENHARO, A. Colonização e trabalho no Brasil: Amazônia, Nordeste e Centro-Oeste. Os anos 30. 2. ed. Campinas: Ed. Unicamp, 1986a. p. 53.

${ }^{67}$ MOREnO, G. Terra e Poder em Mato Grosso: política e mecanismos de burla (1892-1992). Cuiabá: Entrelinhas/EdUFMT, 2007. p. 126.

68 VASCONCELOS, C. A. de. Colonização e especulação fundiária em Mato Grosso: a implantação da Colônia Várzea Alegre (1957-1970). p. 30.
} 


\section{A colonização e as disputas politicas na revista}

Quando assumia o mandato o governador João Ponce de Arruda (PSD), o segundo editorial da revista Brasil-Oeste foi dedicado especialmente para tecer comentário sobre a posse do novo governador estadual. Sob o título de Novo Govêrno de Mato Grosso, o texto iniciava da seguinte maneira:

O Dr. João Ponce de Arruda assume o Govêrno de Mato Grosso em condições excepcionalmente favoráveis [...] Fora das fronteiras, vê o seu Estado melhor compreendido $e$ mais respeitado, mercê da conduta correta que pautou a administração anterior, fazendo-se cumprir os compromissos assumidos pelo Govêrno. ${ }^{69}$

Esse primeiro trecho do editorial deixa claro que, na visão do editorialista, a vitória de João Ponce de Arruda significava que ele tinha em suas mãos grande responsabilidade, sobretudo porque o estado de Mato Grosso encontrava-se em "condições excepcionalmente favoráveis", deixadas pelo governador Fernando Corrêa da Costa (UDN), rival político de Arruda (PSD) ${ }^{70}$ A postura da revista em relação ao novo governo evidencia-se no decorrer do editorial e fica tensionada entre a "pressão" e o "aconselhamento" ao recém-eleito governador, a qual pode ser percebida em trechos como este:

"é natural a exacerbação de ânimos gerada na campanha eleitoral de Outubro de 1955 [...] o Dr. João Ponce de Arruda, assume, portanto, grave responsabilidade como o mais alto magistrado de Mato Grosso. Caberá a S. Excia. a tarefa gigantesca de proporcionar a seus concidadãos o bem-estar e a prosperidade". ${ }^{71}$

Nota-se que há uma evidente tentativa de exercer pressão sobre o novo governo para que continuasse a trilhar os caminhos abertos por Fernando Corrêa da Costa. Será nos

\footnotetext{
${ }^{69}$ Revista Brasil-Oeste, ano I, n. 2, fevereiro de 1956, São Paulo (SP), p. 1. Os grifos são nossos.

${ }^{70}$ Sobre o tema, cf.: NEVES, M. M. R. de N. Elites politicas: competição e dinâmica partidário-eleitoral (caso de Mato Grosso). Rio de Janeiro: Ed. Vértice, 1988.

${ }^{71}$ Revista Brasil-Oeste, ano I, n. 2, fevereiro de 1956, São Paulo (SP), p. 1. Os grifos são nossos.
} 
dois parágrafos finais desse editorial de "boas-vindas" ao governador João Ponce de Arruda que fica nítida a tentativa de pautar as políticas públicas daquele mandato que se iniciava, sobretudo, em relação àquilo que era entendido como carro-chefe para o desenvolvimento da região: colonização e terras. Diz o texto:

[...] S. Excia. tem diante de si vasto plano de colonização em pleno desenvolvimento e deverá definir a êsse respeito a política que melhor atenda aos imperativos de Mato Grosso. É de crer-se que agirá com a devida prudência, neste particular, pois que não poderá prescindir o Estado da cooperação das emprêsas de colonização para um maior aceleramento do progresso.

[...] As inovações, muitas vezes ditadas por motivos egoístas ou partidários, são geralmente fatais para os Estados que dispõem de recursos bastante limitados para a realização de obras de grande envergadura. ${ }^{72}$

É perceptivel que havia uma preocupação especial em relação às questões de colonização e terras que, na concepção do editorialista, progrediram no governo Fernando Corrêa da Costa. Esse editorial intentava pautar as tarefas e medidas que deviam ser tomadas pelos novos governantes, para que o interesse público (mato-grossense) fosse atendido. Assim, a Brasil-Oeste antecipava-se e pretendia dirigir as atividades do aparelho estatal para que as consequências das atitudes governamentais fossem favoráveis a Mato Grosso.

Contudo, é possivel notar uma situação intrigante no que diz respeito ao comportamento da Brasil-Oeste em relação ao governo de João Ponce de Arruda. Durante boa parte do mandato desse governador mato-grossense, as críticas em relação ao seu governo estiveram muito presentes nos textos da revista. A maior parte das opiniões emitidas (velada ou explicitamente) nos artigos e reportagens era desfavorável ao governo de Arruda, e mais; em nenhum dos textos analisados encontramos menções elogiosas em relação às políticas públicas do então chefe do executivo mato-grossense.

${ }_{72}$ Revista Brasil-Oeste, ano I, n. 2, fevereiro de 1956, São Paulo (SP), p. 1. Os grifos são nossos. 
O que pode justificar esse posicionamento? Qual era a política de governo de João Ponce de Arruda que pode explicar as criticas que ele recebeu da revista Brasil-Oeste?

Conforme mencionado há pouco, na análise do editorial Novo Govêrno de Mato Grosso, a posição do redator era de cautela em relação ao recém-chegado governante do Estado. Como também foi possivel notar, João Ponce de Arruda não foi nem um pouco cortês com seu antecessor nas Mensagens Governamentais pronunciadas na Assembleia Legislativa de Mato Grosso. A primeira delas, datada do mês de junho de 1956, teve uma especial apreciação feita no artigo, "Um Documento Desalentador", escrito por alguém com o pseudônimo "De um observador econômico" e publicado na revista Brasil-Oeste. Nesse texto, foi feita uma severa crítica à mensagem do governador, considerada, na sua totalidade, "um documento vazio de conteúdo".

A crítica que se fez residia no fato de que João Ponce não havia apresentado um programa de governo embasado e sólido, sob o ponto de vista do articulista, que constrói seus argumentos fazendo uma relação entre o novo governante e o seu predecessor, que, por sua vez, quando citado, foi elogiado sobremaneira:

A leitura da Mensagem do Governador João Ponce de Arruda, dirigida à Assembléia Legislativa de Mato Grosso, deixa, a quem a conclui, a impressão de um documento vazio de conteúdo $[\ldots]$

Sucedendo em 31 de Janeiro passado a um Govêrno - do Sr. Fernando Correia da Costa - tido como o mais construtivo que houve em Mato Grosso e que deixou em tão edificante situação financeira e econômica o Estado, cuja renda fêz triplicar em cinco anos, sem aumento nos impostos, era de esperar-se que o Sr. João Ponce de Arruda trouxesse, na sua primeira fala à Assembléia, o programa de sua ação governamental, capaz de sobrepor-se à obra administrativa de seu antecessor e de atrair a atenção do país para o portentoso Estado. [...]

A sua orientação, refletida na primeira Mensagem aos representantes do povo não abona a objetividade do engenheiro, que é S. Excia.: não revela o administrador experimentado em 
várias funções, que se aguardava, e nem o estadista que a hora atual reclama para Mato Grosso, o que é desalentador. ${ }^{73}$

O que se pode abstrair desse texto é que não foi colocado em pauta nenhum dos problemas de ingerência na questão dos contratos de terras envolvendo a administração anterior. Tampouco foi feita menção às críticas apontadas pelo governador João Ponce de Arruda ao seu antecessor. Muito pelo contrário, o articulista só fez elogios ao governador Fernando Corrêa da Costa, que deixou "edificante situação financeira e econômica o Estado". Esse artigo foi publicado no quinto número da Brasil-Oeste, do mês de setembro de 1956, e é um indicativo de como se posicionavam os articulistas do periódico em relação ao novo governante.

Um ano antes, na primeira edição da obra Retrato de Mato Grosso, o diretor-proprietário da revista, Fausto Vieira de Campos, dedicou um capítulo especial para debater sobre a colonização no estado e, tal como o articulista da Brasil-Oeste, fez elogios ao então governador Fernando Corrêa da Costa. O autor consagrou algumas páginas para mostrar uma série de dados que evidenciavam os avanços conquistados pelo modelo de gestão dos negócios, envolvendo as terras de Mato Grosso naquela gestão administrativa. Iniciava o capítulo dissertando sobre a legalidade daquele plano governamental que visava "ampliar o território civilizado", criando assim "a oportunidade que possibilita ao homem a concretização de um desejo justo de progresso e de bem-estar". ${ }^{74}$ Ressaltou ainda a questão da segurança que o estado tinha na elaboração desses contratos, uma vez que as empresas deviam cumprir com "condições específicas" e oferecer "garantias, que se estendem desde o rígido respeito das disposições de leis federais e estaduais, até o requisito básico da capacidade financeira" ${ }^{75}$

Ao que tudo indica, a maioria desses contratos demons-trava que houve irregularidades e garantias não cumpridas.

\footnotetext{
${ }^{73}$ Revista Brasil-Oeste, ano I, n. 5, setembro de 1956, São Paulo (SP), p. 12.

${ }^{74}$ CAMPOS, Fausto Vieira de. Retrato de Mato Grosso. São Paulo: Sem editora, 1955, p. 94.

${ }^{75}$ Ibidem, p. 94.
} 
Contudo, Fausto Vieira de Campos evidenciava muito otimismo, pois, sob seu ponto de vista, a colonização particular, se fosse feita dentro das normas, era o melhor caminho para fazer progredir o estado de Mato Grosso, por duas razões principais. Nas palavras do autor, a venda de terras devolutas, "além de forçar a receita do Estado, favoreceu perspectivas melhores para Mato Grosso, em virtude do afluxo de colonos para as novas áreas [...] A política de terras do Governador Fernando Corrêa da Costa é a que melhor atende aos interesses de Mato Grosso". ${ }^{76}$

Fausto Vieira de Campos argumentava em favor de suas ideias, mostrando elementos que confirmavam sua tese de que a colonização por meio de particulares era o melhor caminho, uma vez que, apesar de toda a imensidão e riqueza do território mato-grossense, "cinco vezes maior do que a área total do Estado de São Paulo" existia, no ano de 1953, "apenas 558.000 habitantes". ${ }^{77}$ Ainda em comparação com os paulistas, ressaltava que "nêsse mesmo ano de 1953 a população do Estado de São Paulo era estimada em 9.837.000 habitantes". ${ }^{78}$ É importante frisar, mais uma vez, que o lugar ideal de desenvolvimento para o jornalista era também o estado de São Paulo, assim como para os governantes de Mato Grosso.

Na reedição de Retrato de Mato Grosso (1960), Campos foi obrigado a acrescentar e comentar os escândalos, envolvendo a gestão do então ex-governador Fernando Corrêa da Costa, acusado por parte da imprensa e pelo seu sucessor, João Ponce de Arruda. Contudo, o autor não dedicou muito espaço ao tema. Resumiu seus comentários apenas para descrever esses acontecimentos. Sobre os contratos com as colonizadoras de terras, dizia ele que a validade "daqueles contratos de colonização foi contestada por dirigentes do PSD-MT, originando-se demanda, que culminou com o reconhecimento pelo Congresso Nacional de uma situação sub judice" ${ }^{79}$

\footnotetext{
${ }^{76}$ Ibidem, p. 96-97.

${ }^{77}$ Ibidem, p. 97.

${ }^{78}$ CAMPOS, Fausto Vieira de. Retrato de Mato Grosso. São Paulo: Sem editora, 1955. p. 97.

${ }^{79}$ CAMPOS, Fausto Vieira de, Retrato de Mato Grosso. São Paulo: Brasil-Oeste Editôra, 1960. p. 194. Os grifos são do original.
} 
O autor cita a Mensagem Governamental de junho de 1959, quando João Ponce de Arruda tornava público o julgamento feito pelo Senado e as medidas que seriam tomadas, conforme citado anteriormente, ou seja, que de todas as 22 empresas particulares envolvidas naquele escândalo, apenas cinco delas cumpriram parte dos contratos e houve uma renegociação entre elas e o estado.

Fausto Vieira de Campos emitiu sua opinião, demonstrando insatisfação com as atitudes do novo governador. Dizia ele:

As declarações do Governador Ponce de Arruda expressam, de maneira iniludivel, recuo do Govêrno de Mato Grosso, que abandona formalmente o plano de colonização desenvolvido na administração do Governador Fernando Corrêa da Costa, para forçar a venda das terras comprometidas por contratos.

Se os interêsses do Estado coincidem com os interêsses do povo, é de ver-se que os contratos de colonização somente beneficiavam ao Estado de Mato Grosso, pois visavam a promover o progresso em áreas despovoadas e improdutivas e evitavam que elas fôssem vendidas, pura e simplesmente, aos que não assumiam outras obrigações, além de fazer medir e demarcar as terras.

As emprêsas que estão operando nesse domínio fazem-no com o próprio esforço e com os próprios riscos. ${ }^{80}$

No trecho citado, nota-se que, mesmo após os escândalos envolvendo o governo de Fernando Corrêa da Costa, Fausto Vieira de Campos ainda considerava aquele modelo como ideal para a colonização do Estado. O autor achava que as companhias colonizadoras ficariam demasiadamente prejudicadas com a nova modalidade implantada por João Ponce de Arruda, pois afastaria novos investidores, uma vez que as terras pertinentes aos contratos não cumpridos daquelas empresas deviam ser adquiridas somente mediante a compra direta por parte das colonizadoras, sem a intervenção do estado no processo de colonização.

${ }^{80}$ Ibidem, p. 194. 
Anos antes, em 1956, na sexta edição da Brasil-Oeste, um artigo foi escrito sob o título "Desestímulo à Colonização no Estado de Mato Grosso". Nesse texto, assinado somente pelas iniciais "A.M.T", comentava-se uma entrevista dada por João Ponce de Arruda ao jornal Folha da Manha ${ }^{81}$ de São Paulo, em que o governador dizia que havia a necessidade de se distinguir os bons e maus colonizadores de terras em Mato Grosso e, por essa razão, diversas concessões estavam em investigação, em decorrência das irregularidades da administração anterior. Assim, o autor do artigo da Brasil-Oeste não poupou as críticas, dizia ele que Arruda estaria "sustentando atitude dúbia com respeito às emprêsas colonizadoras, criando em torno delas um ambiente de prevenção que não se justifica[va] de maneira alguma", ${ }^{82}$ ou seja, colocando as concessões de terras sob investigação, o novo governador estaria, na visão do articulista, afugentando novos investidores, receosos e temerosos com essa decisão.

Contudo, o trecho mais emblemático desse texto iniciase sob o seguinte questionamento: "Concessão ou Contrato?”. Dizia ele, na tentativa de defender a administração anterior que:

Fernando Corrêa da Costa não fêz nenhuma concessão de terras com áreas superiores a 10.000 hectares, mas, tão sòmente, firmou contratos com diversas companhias visando à colonização de glebas de terras no Norte do Estado, os quais acautelam os interêsses de Mato Grosso, pois que as emprêsas atuariam como meros agentes do Estado e venderiam lotes (com áreas nunca superior a 2.000 hectares a uma mesma pessoa) depois de aprovados os preços pelo próprio Estado. ${ }^{83}$

Continua o autor ressaltando que, se houvesse qualquer tipo de irregularidade, o que tinha de ser feito era "exigir das companhias o cumprimento das cláusulas contratuais e aplicar-lhes, no caso de inobservância das mesmas, no prazo

\footnotetext{
${ }^{81}$ Jornal Folha da Manhã, quinta-feira, 13 de setembro de 1956, São Paulo (SP). Disponivel em: Banco de Dados Folha: <http://bd.folha.uol.com.br/>. Acesso em: 24 mar. 2011.
}

82 Revista Brasil-Oeste, ano I, n. 6, outubro de 1956, São Paulo (SP), p. 23.

${ }^{83}$ Revista Brasil-Oeste, ano I, n. 6, outubro de 1956, São Paulo (SP), p. 23. 
estipulado, as sanções cabiveis". ${ }^{84} \mathrm{O}$ que merece ser destacado é a tentativa do autor em defender, a todo custo, o processo de colonização do governo Fernando Corrêa da Costa. Conforme já pude mencionar anteriormente, tudo indica que de fato não se tratavam de vendas diretas para as colonizadoras com áreas superiores aos 10.000 hectares, o que significa dizer que há certa pertinência nos argumentos levantados por ele. No entanto, o que realmente pretendo mostrar é o grau de subjetividade desse texto, inegavelmente preocupado com os rumos que foram tomados durante a gestão de Ponce de Arruda, que estaria fazendo ruir todo o processo de desenvolvimento supostamente alcançado nos últimos cinco anos na gestão de Corrêa da Costa.

O articulista continua dizendo que o governador João Ponce de Arruda conseguiu fazer foi "confundir o povo e dar-lhe a falsa impressão de que o então Governador do Estado estava infringindo os dispositivos constitucionais com a celebração de contratos de colonização". Se não bastasse isso, prossegue, dizendo: "é claro que, agora, depois de haver sido a questão apresentada na Câmara Alta, de forma tão inquinada de vícios, nada poderá fazer o Govêrno de Mato Grosso, sem o pronunciamento daquela Casa do Legislativo". ${ }^{85}$ Vale lembrar que, naquela ocasião, ainda se esperava pela decisão final do Senado Federal.

Para finalizar, A. M. T escrevia que, em decorrência dessa atitude do PSD, representado "particularmente" pelo "Senador Filinto Müller ${ }^{86}$ e o Governador João Ponce de Arruda", havia sido criado no estado de Mato Grosso "uma situação deveras lamentável [...] aventando dúvidas sôbre os negócios de terras que estão fazendo as emprêsas colonizadoras". ${ }^{87}$ Conclui o autor que, o pior "é que essas dúvidas têm reflexos

\footnotetext{
${ }^{84}$ Revista Brasil-Oeste, ano I, n. 06, outubro de 1956, São Paulo (SP), p. 23.

${ }^{85}$ Revista Brasil-Oeste, ano I, n. 6, outubro de 1956, São Paulo (SP), p. 23. Os grifos são nossos.

${ }^{86}$ Filinto Müller foi um influente político do estado de Mato Grosso desde o período do Estado Novo. Foi senador em 1947-1951 e 1955-1973. Para maiores detalhes, cf.: ABREU, A. A. de. (et. al.) Dicionário histórico-biográfico brasileiro pós-1930. 1. ed., Rio de Janeiro: Ed. FGV; CPDOC, 1984, p. 2342-2346.
}

${ }^{87}$ Revista Brasil-Oeste, ano I, n. 6, outubro de 1956, São Paulo (SP), p. 23. 
perniciosos em todos os negócios de terras, o que está criando desconfianças e incertezas com respeito às transações dêsse gênero em Mato Grosso". ${ }^{88}$

Os problemas envolvendo a investigação sobre o processo de colonização de terras e as críticas que foram feitas pela revista se estendiam a outras esferas da administração de João Ponce de Arruda. Em artigo publicado no mês de outubro de 1958, sob o título "Ausência do Govêrno de Mato Grosso", foram colocadas em pauta as razões que afastavam o direcionamento editorial da Brasil-Oeste (e aquilo que eles acreditavam ser o ideal para desenvolvimento para o estado) daquela gestão estadual. Não há assinatura no artigo, mas o articulista falava em nome da revista, o que significa dizer que é muito provável que tenha sido escrito por Fausto Vieira de Campos. Iniciava-o dizendo: "Amigos e leitores escrevem-nos, com freqüência, comentando a ausência do Govêrno de Mato Grosso na cruzada que estamos sustentando. Devemo-lhes, portanto, uma explicação."\$9

Quando o autor se refere à "ausência do Govêrno" na "cruzada" empreendida pela revista, isso significa dizer que os ideais de cada uma dessas esferas estavam em caminhos distintos, ou até mesmo, opostos. Ao que nos parece, as constantes críticas feitas ao governador João Ponce de Arruda renderam acusações contra a revista Brasil-Oeste, pois é possivel observar que, nesse artigo, o articulista fez de tudo para se defender de possiveis ataques, que me parece terem sido feitos por partidários do PSD ou até mesmo por leitores "comuns", que pediam respostas, uma vez que era inegável a inclinação favorável às políticas adotadas por Fernando Corrêa da Costa, da UDN.

Continua ele ressaltando que o projeto da revista, estaria assentado em "bases próprias", isto é, "no apôio do Comércio e da Indústria, que se utilizam dos bons veículos de propaganda para fazer a cobertura de seus produtos. Estamos situados, portanto, no lugar certo, como órgão de Imprensa

\footnotetext{
${ }^{88}$ Revista Brasil-Oeste, ano I, n. 6, outubro de 1956, São Paulo (SP), p. 23.

${ }^{89}$ Revista Brasil-Oeste, ano II, n. 18, outubro de 1957, São Paulo (SP), p. 32. Os grifos são nossos.
} 
livre". ${ }^{90}$ Nota-se que há uma notável tentativa de responder a qualquer tipo de acusação que insinuasse que a revista recebia ajuda financeira de segmentos politicos oposicionistas ao governador João Ponce de Arruda.

É o discurso da objetividade jornalística. Apesar de parecer que de fato havia afinidades com o então ex-governador Fernando Corrêa da Costa em oposição ao governo Ponce de Arruda, os responsáveis pelo periódico faziam questão de frisar a sua independência frente a grupos politicos ou econômicos. Continua o autor: "não sofremos pressão de frações político-partidárias, nem ingerência de grupos econômicos [...] A politica que sustentamos [...] situa-se num plano muito alto e, por isso mesmo, só é realizável por homens capazes e independentes". ${ }^{91}$

O maior problema contido nessas afirmações reside no fato de que alguns artigos (quando assinados) que criticavam o governador João Ponce de Arruda vinham de partidários de Fernando Corrêa da Costa, como foi o caso de Demóstenes Martins que, em algumas ocasiões, utilizou o espaço da revista para expor seu posicionamento de defesa do governo anterior e de ataque ao seu sucessor.

Vale a pena relembrar o fato de que Fausto Vieira de Campos se tornou assessor de imprensa de Fernando Corrêa da Costa com indicação feita por Demóstenes Martins (Secretário de Agricultura Estadual da época). Antes disso, contudo, o então correspondente da Folha da Manhã em Mato Grosso teve fortes laços de amizade com Dormevil Faria, outro mato-grossense que fez carreira politica pela UDN, o que sugere que foi por meio deste último que Fausto iniciou seu contato com Martins.

Mais um importante colaborador da Brasil-Oeste também teve participação crucial no governo da UDN. Tratava-se do engenheiro agrônomo José Bardauil, designado pelo então governador, no ano de 1951, para reorganizar o Departamento

\footnotetext{
${ }^{90}$ Revista Brasil-Oeste, ano II, n. 18, outubro de 1957, São Paulo (SP), p. 32. Os grifos são nossos.

${ }^{91}$ Revista Brasil-Oeste, ano II, n. 18, outubro de 1957, São Paulo (SP), p. 32. Os grifos são nossos.
} 
de Terras e Colonização. Fernando Corrêa da Costa disse naquela ocasião que tal indicação foi feita "a fim de serem atendidos satisfatòriamente pela administração os problemas de terras, colonização e cooperativismo". ${ }^{92}$ Entenda-se como "problemas", a "má administração" do governo anterior (de Arnaldo Estevão de Figueiredo) em relação aos negócios envolvendo as terras de Mato Grosso.

Diversos foram os colaboradores da revista Brasil-Oeste que estavam associados à base do governo de Fernando Corrêa da Costa, tais como, Dolor de Andrade, Paulo Jorge Simões Corrêa, Wilson Barbosa Martins, Yttrio Corrêa da Costa, René Barbour, Lenine de Campos Povoas e Edson Brito Garcia.

Essas evidências provocaram especulações na época em que a revista circulou, uma vez que foi acusada de "ser" udenista. Como foi mostrado há pouco, foi preciso Fausto Vieira de Campos escrever um texto, mostrando que [aquele projeto] estava alheio às "pressões partidárias". O texto em que o diretor da Brasil-Oeste dá explicações perante o seu leitor sobre essas pressões foi publicado na edição de número 18. Porém, anos mais tarde, no número 49, ou seja, já no final do mandato de João Ponce de Arruda, outra vez o diretor tentou se justificar e negar qualquer inclinação politica por parte do projeto em que estava empenhado.

Esse pronunciamento aconteceu na oportunidade em que a revista Brasil-Oeste foi homenageada pela Câmara Municipal de Campo Grande, no mês de maio de 1960, quando Fausto Vieira de Campos foi ao estado de Mato Grosso para cobrir uma feira agropecuária. Naquela ocasião, os líderes dos três partidos que se faziam representados naquele municipio (PSD, PTB e UDN) manifestaram o apoio ao empreendimento jornalístico capitaneado por Campos. Aproveitando-se disso, o diretor da Brasil-Oeste fez um discurso, reproduzido em partes na edição de junho de 1960, que dizia o seguinte:

A revista BRASIL-OESTE tem um programa definido. Acontece, porém, que a UDN fôra o primeiro agrupamento partidário

92 Mensagens Governamentais do Governador Fernando Corrêa da Costa, 1952, p. 41. 
que apoiou êsse programa, prestigiando a revista sem fazer-lhe a menor solicitação de reciprocidade. Os demais partidos políticos retardaram êsse apôio. Disso resultou o falso conceito de que a BRASIL-OESTE é uma "revista udenista..." [Fausto] Esclareceu que todos os partidos foram convidados a manter na BRASIL-OESTE uma tribuna livre, apenas condicionados ao estrito respeito da Lei de Imprensa. A UDN e o PSD aceitaram o oferecimento e o PSP e o PTB estavam cientificados. Com essa decisão, a BRASIL-OESTE visa a forçar o intercâmbio das idéias, a congraçar eleitores, a romper as barreiras da intolerância política, a proporcionar ao povo o ensejo de cotejar as diretrizes dos partidos e dos seus candidatos aos postos eletivos, possibilitando-o, assim, de fazer melhores escolhas..$^{93}$

Apesar do discurso defensivo, emitido por meio da tribuna da Câmara Municipal de Campo Grande, somado àqueles que eram transmitidos nas páginas da Brasil-Oeste, em que se destacavam objetividade, independência politica e econômica, seus textos dão possibilidades ao leitor de interpretá-los de forma inversa. Além das críticas, envolvendo as questões relacionadas às terras e colonização de Mato Grosso, outras tantas foram feitas no âmbito da própria organização administrativa do governo Ponce de Arruda, sempre fazendo oposição entre esse "mau governo" e a "visão administrativa" de Fernando Corrêa da Costa.

Esse foi o caso do texto intitulado "Inoperância administrativa", publicado na sexta edição da revista, novamente sob a assinatura "De um Observador Econômico". Logo no primeiro parágrafo desse artigo, o autor indicava que o novo governo instalado no estado de Mato Grosso repetia vícios dos anteriores (com exceção de Fernando Corrêa da Costa), inflando as despesas com o funcionalismo público. Dizia ele:

[...] a despeito das esperanças acalentadas, Mato Grosso está retornando àquêles tempos de antanho em que a ação governamental se exprimia pela atividade única de cobrar impostos e pagar funcionários, em cujos estipêndios se consumiram $80,60 \%$ da arrecadação do exercício, em $1950 .{ }^{94}$

93 Revista Brasil-Oeste, ano V, n. 49, junho de 1960, São Paulo (SP), p. 65. Maiúsculas do original.

${ }^{94}$ Revista Brasil-Oeste, ano I, n. 6, outubro de 1956, São Paulo (SP), p. 18. 
Esse é o típico caso que acontece quando um novo grupo político assume o governo de uma determinada região; contratam-se diversos aliados e demitem-se os oposicionistas, formando no interior dos governos aquilo que é conhecido como "cargo de confiança". O autor indicava que, com a subida de João Ponce de Arruda ao poder, essa situação se agravava, aumentando os "estipêndios" e consumindo mais uma vez boa parte do dinheiro dos cofres públicos.

Abre-se um parêntese para mostrar que, em editorial publicado na edição número 3 da Brasil-Oeste, sob o título Governos Punitivos, encontra-se um tipo de critica velada aos governantes que, quando assumem suas cadeiras, "perseguem" funcionários de administrações anteriores, demitindoos. O discurso presente nesse texto é importante, pois se aproxima daquilo que Beltrão chama de editorial preventivo, isto é, aquele "se antecipa à realidade, apontando situações", ${ }^{95}$ que acontecem num determinado momento e, nesse caso específico, iriam prejudicar o estado de Mato Grosso:

Notícias que nos chegam de dois dos Estados onde se renovaram os Governos, em 31 de Janeiro último, adiantam que se desencadeou, neles, ofensiva em regra contra funcionários públicos que contem menos de cinco anos de exercício no cargo.

Ao mesmo tempo, iniciou-se, nos referidos Estados, uma sequência de inquéritos sôbre as administrações passadas [...] [estão cometendo erros os] Governadores empossados em 31 de Janeiro, com a agravante de que não podem justificar seus atos com pretextos de economia para o Erário Público, porquanto, à medida que os preteridos são postos no ôlho da rua, o lugar vago é preenchido com a nomeação do cidadão eleito pelas preferências do partido dominante [...]

Está evidente, por conseguinte, que a derrubada do funcionalismo tem caráter estritamente político-partidário, e essa diretiva dos novos governantes só pode comprometer os interêsses públicos e avivar descontentamentos e desconfianças. ${ }^{96}$

${ }_{95}^{5}$ BELTRÃO, L. Jornalismo Opinativo. Porto Alegre: Sulina, 1980, p. 56.

${ }^{96}$ Revista Brasil-Oeste, ano I, n. 3, março de 1956, São Paulo (SP), p. 1. Os grifos são nossos. 
Nota-se que a oposição às novas medidas tomadas pelos governadores que iniciavam seus mandatos fica muito clara. Critica-se veladamente Ponce de Arruda, sem citá-lo diretamente, mas a alusão à sua gestão é visível, sobretudo, quando se ressaltam os inquéritos "sôbre as administrações passadas", o que remete diretamente às questões envolvendo os problemas de terras e colonização do governo Fernando Corrêa da Costa.

Voltando ao texto anterior, continua o "Observador Econômico", fazendo seu balancete do governo Arruda, comparando-o com seu antecessor, Fernando Corrêa da Costa:

Impulsionada a administração do Estado pela probidade, visão do conjunto e operosidade do ex-Governador Fernando Correia da Costa, a longinqua Provincia do Oeste ganhou relêvo no panorama da ação construtiva dos nossos governos. Os "déficits" orçamentários foram banidos [e] a divida pública reduziu-se $[\ldots]$

Ao balancear-se o ativo do Govêrno transato em relação aos que o procederam, constata-se que êle foi o mais operoso nesta meia centúria de administração em Mato Grosso. ${ }^{97}$

A partir daí, o autor cita diversas ações feitas pelo governo de Corrêa da Costa, inclusive no âmbito da colonização, que foi feita "através da cooperação de emprêsas privadas". Construídos os seus argumentos em favor do representante da UDN, continua a tecer suas críticas ao governador do PSD e pergunta: "Legatário de tão grande acervo de realizações e empreendimentos, que fêz o atual Govêrno do Sr. João Ponce de Arrruda, neste ano prestes a extinguir-se?" Continua criticando a descontinuidade das ações iniciadas pela administração anterior, enfatizando, mais uma vez, a questão das terras, dizendo que "as emprêsas colonizadoras quedam-se estacionárias diante das ameaças de elementos do Govêrno de que a orientação vai ser modificada completamente". ${ }^{98} \mathrm{E}$ completa seu raciocínio com duríssimas críticas:

${ }^{97}$ Revista Brasil-Oeste, ano I, n. 6, outubro de 1956, São Paulo (SP), p. 18. Os grifos são nossos.

${ }^{98}$ Revista Brasil-Oeste, ano I, n. 6, outubro de 1956, São Paulo (SP), p. 18. Os grifos são nossos. 
A atividade governamental neste ano, até agora, tem-se cingido à tarefa de exonerar funcionários, cujos atos já ultrapassam de mais de 3.000, para colocar correligionários do situacionismo e, quando êles não existem, as vagas não se preenchem, deixando-se os cargos acéfalos, como tem acontecido com numerosas escolas rurais.

O Governador [...] quando profere discursos é em tom polêmico para dizer que tudo estava errado, mas não mostra o rumo certo que vai perlustrar. Enquanto isso, modorram alguns milhões de cruzeiros no Tesouro o que vem positivar que estamos à frente de uma inoperância governamental sacrificadora do desenvolvimento do grande Estado, repositário de um extraordinário potencial de riquezas naturais. ${ }^{99}$

A partir da análise de textos como esse, nota-se que o discurso de objetividade jornalística fica enfraquecido, e a inclinação em favor das políticas públicas empreendidas no governo de Fernando Corrêa da Costa apresenta-se muito claramente. Como se percebe, é justamente nas críticas ao novo governante que as comparações com o anterior ficam mais evidentes, pois o parâmetro de "ideal" de governo era aquele representado por Corrêa da Costa: "impecável" na administração e que elevou Mato Grosso a um patamar "jamais atingido" anteriormente.

O tema envolvendo as terras e colonização foi se esgotando com o decorrer dos anos. Então, na edição número 42 , do mês de novembro de 1959, estampava-se a seguinte manchete: "Fim melancólico da COLONIZAÇÃO (OFICIAL) EM MATO GROSSO, Glebas compromissadas com as companhias postas à venda como terra devolutas". ${ }^{100} \mathrm{O}$ título do principal artigo dessa edição era "Tarefa exclusiva da iniciativa particular a colonização no Estado de Mato Grosso". Esse texto não tinha assinatura, mas, ao que tudo indica, foi escrito por Fausto Vieira de Campos, pois alguns trechos de igual conteúdo também se encontravam na obra Retrato de Mato Grosso.

Nesse artigo, há uma mistura de revolta em relação às medidas tomadas por João Ponce de Arruda, e forte apelo é

\footnotetext{
${ }^{99}$ Revista Brasil-Oeste, ano I, n. 6, outubro de 1956, São Paulo (SP), p. 18.

${ }^{100}$ Revista Brasil-Oeste, ano V, n. 42, novembro de 1959, São Paulo (SP). Capa. Maiúsculas do original.
} 
dirigido ao governador para que fossem tomadas "medidas justas" em relação ao problema das terras, pois as companhias colonizadoras e diversos investidores estariam sendo afugentados em decorrência de tantas acusações políticas, impasses e entraves envolvendo a colonização.

$\mathrm{O}$ autor iniciava o artigo tecendo os costumeiros elogios ao ex-governador Fernando Corrêa da Costa. Enfatiza que, entre os anos de 1951 e 1955, o "Govêrno de Mato Grosso pôs em prática vasto plano de colonização [...] com o concurso de emprêsas particulares". ${ }^{101}$ Continuava o articulista ressaltando que havia garantias e confiança entre o estado e as companhias colonizadoras. Dizia ele, no entanto, numa tentativa de justificar os possiveis descalabros daquela gestão, que tal empreendimento (a colonização), traria resultado em longo prazo, sem a rapidez pretendida, nas suas palavras, "tarefa de tamanha envergadura não podia realizar-se, certamente de um dia para o outro, maximé considerando-se as dificuldades que se apresentam para a movimentação de cargas e gente, na região [...] de Mato Grosso". ${ }^{102}$

As acusações feitas ao novo governador João Ponce de Arruda e seus correligionários residiam no fato de que, na visão do articulista da Brasil-Oeste, esse grupo opositor ao governo de Fernando Corrêa da Costa formulou as denúncias justamente para "travar" o sucesso que era o modelo de colonização efetuado pelo governador da UDN.

O autor criticava o estado pelo cancelamento dos contratos de colonização, uma vez que isso afetaria diretamente na arrecadação para os cofres de Mato Grosso, afugentando as empresas colonizadoras. Assim, ele escreveu que "[...] a paralisação das atividades das emprêsas colonizadoras [...] gerou o desânimo, com os reflexos os mais desfavoráveis nos negócios de terras devolutas". ${ }^{103}$ Enfatizava ainda que diversos boatos circulavam em outros estados da nação, por conta dos processos judiciais que envolveram a questão da colonização

\footnotetext{
${ }^{101}$ Revista Brasil-Oeste, ano V, n. 42, novembro de 1959, São Paulo (SP), p. 23.

${ }^{102}$ Revista Brasil-Oeste, ano V, n. 42, novembro de 1959, São Paulo (SP), p. 23.

${ }^{103}$ Revista Brasil-Oeste, ano V, n. 42, novembro de 1959, São Paulo (SP), p. 24. Os grifos são nossos.
} 
de terras e as acusações que foram feitas contra o governo anterior:

Essas versões, muitas vezes, continham significação maliciosa, que punha em xeque a honorabilidade do Govêrno de Cuiabá - pois se dizia, e ainda se diz, que requerimento de terra devoluta só tramita mediante pagamento de tributação extra-legal. ${ }^{104}$

Finaliza o autor fazendo um "apelo" ao governo de Mato Grosso, "em prol de um bem maior", qual seja, o desenvolvimento do estado mediante atração de capitais, e não o contrário:

[...] vimos favorecendo contactos com organizações norte-americanas interessadas em investir capitais no Estado de Mato Grosso. Temos, portanto, o maior empenho em manter a confiança nos negócios que se entabulam, e em desenvolver, cada vez mais as relações entre as emprêsas brasileiras e os capitalistas dos Estados Unidos.

É preciso que não paire dúvida sôbre a legitimidade dos gravames que oneram as transações com terras devolutas. É preciso que se possa dizer que são legais TODOS os tributos que incidem sôbre elas. ${ }^{105}$

Essa citação deixa evidente que o investimento associado entre o capital privado (nacional e estrangeiro) e o público (por parte do Estado) era entendido como o melhor caminho a ser trilhado em beneficio de Mato Grosso. Também nos parece claro que as reportagens e artigos publicados na revista estavam em consonância com as politicas públicas do governo Fernando Corrêa da Costa, mesmo que essa harmonia de ideias fosse veementemente negada pelos diretores do mensário.

${ }^{104}$ Revista Brasil-Oeste, ano V, n. 42, novembro de 1959, São Paulo (SP), p. 24. Os grifos são nossos.

${ }^{105}$ Revista Brasil-Oeste, ano V, n. 42, novembro de 1959, São Paulo (SP), p. 24. Maiúsculas do original. 


\section{Considerações finais}

Quando João Ponce de Arruda subiu ao poder, a dinâmica de colonização mudou radicalmente e tomou corpo uma onda de escândalos envolvendo o governo de Fernando Corrêa da Costa, no que tange aos negócios envolvendo as terras de Mato Grosso - sendo que a posição política da Brasil-Oeste não ficou imune a essas disputas. A direção e o grupo de articulistas que participavam daquele projeto editorial não se conformavam com as acusações dirigidas à gestão anterior, pois entendiam que naquelas denúncias havia muito mais interesses politicos do que uma tentativa de fazer o melhor para a região. Do ponto de vista dos textos escritos na revista, as investigações sobre alienação de terras teriam afastado sobremaneira os investidores para aquela região. Ponce de Arruda foi acusado de acabar com um tipo de projeto que tinha impulsionado Mato Grosso rumo ao desenvolvimento. Ele retirava a função do estado como agente associado, e também fiscalizador, daquelas empresas particulares.

$\mathrm{Na}$ opinião de Fausto Vieira de Campos, João Ponce acabou piorando a situação, pois a partir de então qualquer um poderia colonizar como bem entendesse, desde que pagasse ao estado os valores pertinentes às áreas compradas, o que gerava insegurança também para as empresas que ali se instalavam. Os partidos políticos, PSD e UDN, travavam, já há algum tempo, uma batalha pelo poder no estado de Mato Grosso. Na Brasil-Oeste, como foi demonstrado, havia uma parte dos colaboradores que eram ligados à União Democrática Nacional. Não podemos afirmar com certeza que discussões estavam sendo feitas no interior ou nos corredores da redação da revista sobre tal tema, contudo, a julgar por aquilo que saía nas páginas do mensário, a inclinação udenista era evidente, quer fossem os envolvidos conscientes ou não desse fato. Por mais que Fausto Vieira de Campos argumentasse que eles não tinham posições políticas, seu evidente descontentamento com a gestão do PSD, a parceria com diversos filiados da UDN e seu histórico como assessor do governo Fernando Corrêa da Costa eram alguns dos aspectos que "depunham" contra a objetividade do jornalista que, certamente, recebia 
críticas dos pessedistas e, por essa razão, buscou se explicar frente ao seu público leitor por algumas vezes.

A rigorosa neutralidade do discurso jornalístico enunciada pelos Campos não pôde ser efetivamente praticada na sua ação, tanto do ponto de vista político, quanto do ponto de vista econômico, uma vez que entre os anos de 1956-1959 boa parte dos seus anunciantes estava ligada às empresas colonizadoras. ${ }^{106}$ Certamente, houve uma forte defesa da gestão de Fernando Corrêa da Costa, muito em conta do histórico pessoal dos Campos, mas também pelo modelo de colonização e desenvolvimento defendido pelos diretores da Brasil-Oeste e pelo governo da UDN. Diversas são as questões que ainda devem ser estudadas sobre essa revista. O tema aqui apresentado é um resumo de apenas um tópico dentre diversos outros que podem ser estudados nas páginas que fazem parte da longa história desse periódico, que esteve em circulação por 12 anos, publicou 123 exemplares e vendeu mais de 1.500.000 (um milhão e meio de exemplares).

Resumo: Busca-se neste artigo analisar alguns dos artigos publicados pela revista Brasil-Oeste, mensário que circulou entre janeiro de 1956 e agosto de 1967 e que tinha como objetivo discutir temas que evidenciassem as riquezas e potencialidades econômicas do estado de Mato Grosso. O assunto escolhido para a construção deste trabalho foi a colonização em Mato Grosso na década de 1950. Tal tema foi muito debatido no plano político mato-grossense e, por essa razão, também foi explorado nas páginas da revista. Destacaremos as diferenças e as disputas entre as gestões dos governadores Fernando Corrêa da Costa (1951-1956) e João Ponce de

\footnotetext{
${ }_{106}$ Tal tema não pôde ser aqui analisado em razão das limitações de espaço que são comuns na modalidade de publicação acadêmica do tipo artigo científico, no entanto, nos primeiros quatro anos de circulação da revista Brasil-Oeste, $16 \%$ dos seus anunciantes eram empresas ligadas à colonização e ao setor imobiliário. Esse pode ser um indicativo de que a defesa feita pelo mensário em relação às empresas não era gratuita, pois, segundo os textos da revista, tal segmento (colonização) foi prejudicado depois do cancelamento dos contratos de terras feitos no período de gestão do governador Fernando Corrêa da Costa pelo Senado Federal, mas iniciado pelos partidários do PSD regional de Mato Grosso.
} 
Arruda (1956-1961) sobre tal tema e mostraremos como tais confrontos foram refletidos nas páginas da Brasil-Oeste.

Palavras-chave: Colonização. Revista Brasil-Oeste. João Ponce de Arruda. Fernando Corrêa da Costa.

Abstract: This paper seeks to examine some of the articles published by the Brasil-Oeste magazine, which circulated monthly between January 1956 and August 1967 and aimed at discussing issues regarding the wealth and economic potential of the State of Mato Grosso. The subject chosen for the development of this research was the colonization in the State of Mato Grosso in the 1950s. This theme was much debated in the political field of the State and, therefore, was also explored in the pages of the above-referred magazine. We will seek to emphasize the divergences and disputes between the administrations of Governors Fernando Corrêa da Costa (1951-1956) and João Ponce de Arruda (1956-1961) about the colonization and expose how such clashes were dealt with in the pages of the Brasil-Oeste magazine.

Keywords: Colonization. Brasil-Oeste magazine. João Ponce de Arruda. Fernando Corrêa da Costa.

Artigo recebido para publicação em 02/09/2011

Artigo aprovado para publicação em 18/11/2011 